\title{
Vékony lemez görbületének mérése digitális képfeldolgozás segítségével
}

\section{Curvature Measurement of Thin Plates with the Help of Digital Image Processing}

\author{
Máté Péter, ${ }^{1}$ Szekrényes András ${ }^{2}$ \\ Budapesti Müszaki és Gazdaságtudományi Egyetem, Gépészmérnöki Kar, Müszaki Mechanikai Tanszék, \\ Budapest, Magyarország \\ ${ }^{1}$ peter.mate@mm.bme.hu \\ 2 szeki@mm.bme.hu
}

\begin{abstract}
The verification of different plate bending problems require a punctual measurement method of the bent shape. However, with a proper curvature measurement procedure the calculations can be made more accurate. This is due to the workaround this method provides by neglecting the inaccuracies of the beam theory and the tensile tests, measuring directly the function between the curvature and bending moment for a given sheet metal. The measurements in this paper are made with the help of a digital camera and telephotographic lens. The evaluations of these images are compared to the results obtained from the Euler-Bernoulli beam theory. While the results regarding the curvature measurements have a significant deviation, the shape of the plate is in good agreement with the numerical calculations.
\end{abstract}

Keywords: curvature, thin plate, bending, image processing.

\section{Összefoglalás}

A különböző lemezhajlítási feladatok megoldásának ellenőrzéséhez elengedhetetlen a görbült alak pontos mérése. Ugyanakkor egy, a görbület mérésére alkalmas módszerrel a számítások pontosabbá tehetőek, hiszen a húzóvizsgálat és a rúdelmélet pontatlanságait megkerülve, közvetlenül mérhetővé válik a görbület-nyomaték összefüggés az adott lemez esetén. A dolgozatban szereplő mérések digitális kamera és teleobjektív segítségével készültek el. A mérések eredményei végül összehasonlításra kerülnek az Euler-Bernoulli-rúdelméletből kapható eredményekkel. Bár az eredmények a görbület szempontjából jelentős szórással terheltek, a görbült alak jó egyezést mutat az elméleti numerikus számításokkal.

Kulcsszavak: görbület, vékony lemez, hajlítás, képfeldolgozás.

\section{Bevezetés}

A hajlított rudak, lemezek alakjának számítása elsősorban az adott hajlítónyomaték hatására kialakuló görbület alapján történik. A görbület és nyomaték közötti összefüggés leírására a szakirodalom több elméletet is kínál, ám ezek mind bizonyos megfontolások, közelítések mellett érvényesek, illetve nagyon erősen támaszkodnak az anyagi viselkedést leíró egytengelyű húzóvizsgálatra. A célom ebben a dolgozatban kettős: elsősorban egy olyan eljárás kifejlesztése, amely lehetőséget kínál egy hajlított lemez vagy rúd görbületi eloszlásának mérésére, ezáltal ellenőrizhetővé téve a számításokat. Másodsorban ugyanezen módszer segítségével közvetlen módon mérhetővé válik a görbület és a hajlítónyomaték közti összefüggés, amellyel megkerülhetővé válik a rúdmodell alkalmazása, kiküszöbölve az ezzel hozott elhanyagolások és feltételezések hatását. 


\section{Képalkotás}

Az elsődleges cél a képalkotással az, hogy a lemez középsíkjának a vetületi görbéjét (a továbbiakban középvonal) minél pontosabban leképezzem egy kétdimenziós raszterre. Ebből a szempontból kiemelkedően jó a vékony lemez, hiszen minél vékonyabb, a középvonal pontjai annál nagyobb pontossággal határozhatóak meg.

A képalkotás során ideálisan párhuzamos vetítést kellene alkalmazni, amihez a szkennelés áll a legközelebb, ahogy Kovalevsky (2001) is azt használta tárgyak kontúrjának görbületi elemzéséhez [1]. A mérések elvégzésekor nem állt rendelkezésemre megfelelő képalkotó eszköz, így a lemezek leképezése digitális kamera segítségével történt. Ez a lencserendszer természetéből fakadóan nem ideális megoldás, hiszen a lencsék torzítják a képet, ahogy távolodunk a lencserendszer optikai tengelyétől. A kép pontosságát további tényezők is rontják: ilyen pl., hogy a lemeznek van kiterjedése az optikai tengely mentén, így a centrális vetítés miatt a lemez vastagabbnak látszik a képen. További probléma az, hogy árnyékot vet a papírra, illetve tükröződik a papíron, amelyek miatt a határok elmosódnak.

Azért, hogy ezeket minél jobban kiküszöböljem, és a lemez mégis minél több helyet foglaljon el a képen, teleobjektívvel ellátott fényképezőgép került alkalmazásra, a lehető legszűkebb blendével, és a legnagyobb elérhető nagyításban, úgy, hogy a lemez kitöltse közel a teljes képet. A cél az volt, hogy jól elkülöníthető legyen a lemez a háttértől, ehhez a lemezt kékre festettem, háttérnek pedig egy piros lapot (1. ábra) választottam. A képek egy CANON EOS 1000D-típusú fényképezőgéppel és egy 350 mm-es Sigma objektívvel készültek.

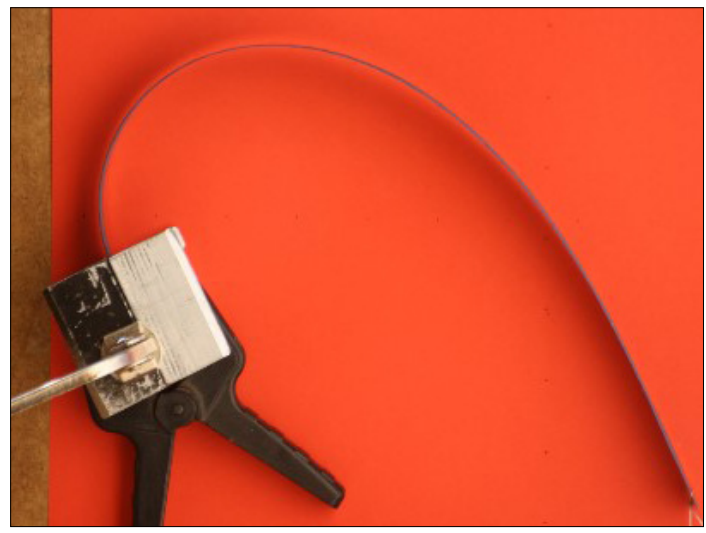

1. ábra. A számításokhoz használt fotó (3888x2592 px)

\section{Képfeldolgozás}

A kép feldolgozásához a HSB-színkoordinátarendszert használtam, ez határozta meg a színválasztását a lemeznek és a háttérnek, hiszen a kék és piros színek ezen a skálán megfelelően elkülöníthetőek egymástól.

A cél a képfeldolgozás során elsősorban a lemez és a háttér elkülönítése. Arra való tekintettel, hogy nem megfelelően kontrollált a képkészítés, először manuálisan, egyedileg kellett a képről eltüntetni mindent, ami nem a lemez és annak szűk környezete. Ezután ugyanezen okból kifolyólag minden képnél egyedi vizsgálatra van szükség, amely után egyedileg meghatározhatóak azok a pixelekre vonatkozó $H$ (árnyalat), $S$ (szaturáció), $B$ (fényesség) határértékek, amelyek alapján már algoritmikusan szűrhetőek a lemezt tartalmazó pixelek. Egy ilyen $H-S-B$ eloszlás látható a 2. ábrán.

\subsection{A kép kiértékelése}

A lemezháttérhatár elmosódása miatt, ahogy a 2. ábrán is látható, nem egyértelmű a lemez peremének a pozíciója. Ennek a megoldásához a kép színadataiból elsősorban egy súlytérképet kell készíteni, ahogy Kovalevsky [1] és Coeurjolly et al. [2] is tette szürke árnyalatos képekkel. Itt a színes kép miatt a 2 . ábrát figyelembe véve kell kialakítani a súlyozás módját. Így mindegyik képponthoz egy súlyt rendelünk, amelyet mátrixba rendezünk $(w)$. A mátrix számítási módját az (1)-es képlet fogalmazza meg, amennyiben a $H, S$, $B$ értékek a megállapított határértékeken belül találhatóak. Minden más esetben a súlyértékzérus.

$$
w_{i j}=\frac{H_{i j}}{S_{i j} \cdot B_{i j}}
$$

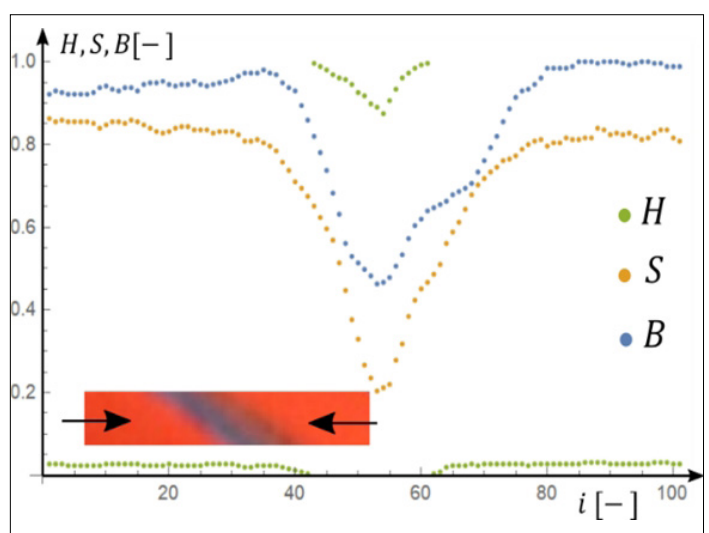

2. ábra. A kép egy pixelsorának $H$, S és B eloszlása a vízszintes pixelkoordináta szerint 


\subsection{Középvonal keresése}

A középvonal koordinátáinak a keresésekor elsősorban a lemezt tartalmazó pixelek koordinátáit átlagoltam, a színadatok alapján számított súlyok segítségével. Ez kétféle algoritmus szerint történhet: a koordinátatengelyek mentén történő átlagolással vagy polárkoordináták segítségével, a sugárirány mentén. A kiértékelés során mindig poláris rendszerben kerestem a súlypontvonalat, mert ez lényegesen simább ponthalmazt adott, mint a Descartes-féle koordinátatengelyek mentén való számítás. A jelenség okának szemléltetése jelleghelyesen a 3. és 4. ábrán látható. A felhasznált, súlypontvonal koordinátáinak poláris rendszerben való számításához használt képletet a (2) egyenlet tartalmazza. A súlymátrix indexei a kép $\left\{x_{i} ; y_{i}\right\}$ koordinátáit reprezentálják, viszont ezeknek természetesen az egész részét kell figyelembe vennie az algoritmusnak. A számítással így egy $\left\{\varphi_{i} ; r_{i}\right\}$ koordinátapárt nyerünk, amelyet vissza kell transzformálni a derékszögű rendszerbe, ezeket a továbbiakban $\left\{x_{i} ; y_{i}\right\}$-vel fogom jelölni.

$$
r_{i}=\frac{\sum_{j} r_{j} \cdot w_{r_{j}} \cdot \cos \left(\varphi_{i}\right), r_{j} \cdot \sin \left(\varphi_{i}\right)}{\sum_{j} w_{r_{j} \cdot \cos \left(\varphi_{i}\right), r_{i} \cdot \sin \left(\varphi_{i}\right)}}
$$

A px mértékegységből mm-be való átváltás a hátteret jelentő papírlapon előre felvett kontrollméretek segítségével történik. Az átváltott, mm mértékegységű koordinátákat $\left\{X_{i} ; Y_{i}\right\}$ jelöli. A nyers pontfelhő az $X$ - $Y$ koordináta-rendszerben az 5. ábrán látható. Ez 5017 db pontból áll.

\section{Görbületszámítás}

A görbület számításához numerikus módszer alkalmazása szükséges, hiszen csak diszkrét pontokban adott a lehajlott lemez alakja. Egy analitikusan adott $f: \mathbb{R} \rightarrow \mathbb{R}, f(x)$ függvény esetén a simulókör görbületének ( $\kappa$ ) számítása a (3) egyenlet szerint történik. Diszkrét pontokkal adott függvény esetén ez a képlet használható, különböző numerikus deriválási sémák alkalmazásával, viszont ezek a sémák érzékenyek arra, hogy a pontfelhő osztása ekvidisztáns legyen [3], ami itt nem valósult meg, így végül a Dalle [3], illetve Belyaev [4] által bemutatott, invariáns diszkrét görbületszámítási módszereket alkalmaztam. Elviekben az invariáns módszerek elsőrendű konvergenciát mutatnak, bár ennek feltétele, hogy a pontok maguk ne rendelkezzenek hibával, ami egy ilyen mérés esetén nem lehetséges. Az adatok hibájának kiküszöbölésére elsősorban egy mozgóablakos simítást alkalmaztam, majd a görbület számításá-

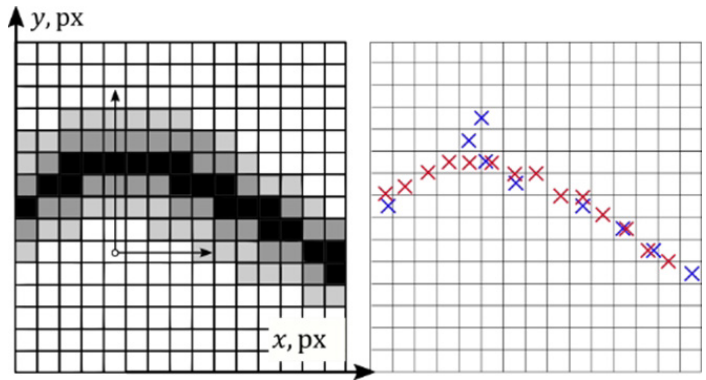

3. ábra. A lemez pontjainak az x és y koordináták mentén való átlagolása

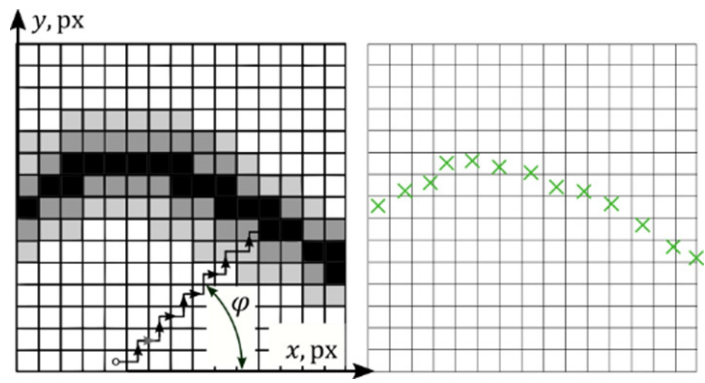

4. ábra. A lemez pontjainak egy kvázi poláris rendszerben való átlagolása

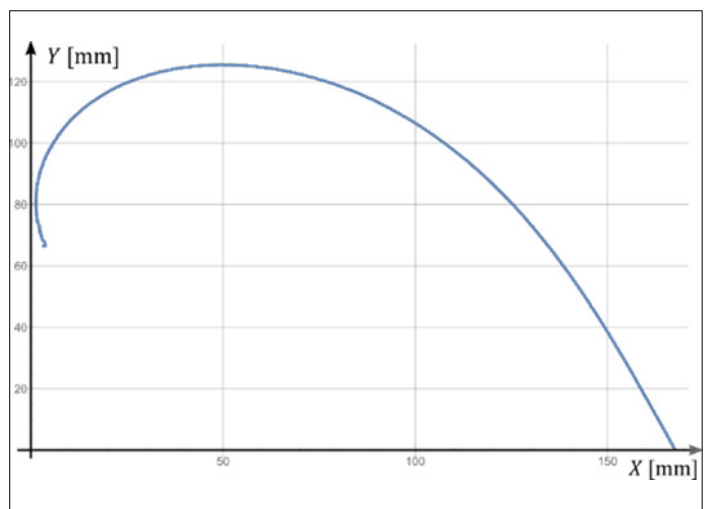

5. ábra. A lemez középvonalát jellemző nyers pontfelhő

hoz használt adatok távolságát növelnem kellett, hogy a nyers adathalmaz zaját csökkentsem és az alakot minél jobban reprezentáló ponthármasokat válasszak.

$$
\kappa=\frac{f^{\prime \prime}(x)}{\left(1+f^{\prime}(x)^{2}\right)^{3 / 2}}
$$

\subsection{Görbület becslése három pontból}

Az egyik legegyszerübb, invariáns numerikus eljárás az, hogy a görbületet a három egymást követő pont által kifeszített háromszög köré írt kör görbületével közelítjük. Az eljárás illusztrációja a 
6. ábrán látható. A körív görbülete ekkor a (4)-es egyenlet szerint adódik, ahol $T_{\Delta}$ a háromszög területe, és Héron képletével számítható.

$$
\kappa \approx \frac{4 \cdot T_{\Delta}}{h_{1} \cdot h_{2} \cdot h_{3}}
$$

\subsection{Görbület becslése függvényillesztésből}

A pontfelhő zajossága miatt egy másik figyelemre méltó módszer a lokális polinomillesztés a legkisebb négyzetek módszere szerint, és a függvény görbületének meghatározása a kiválasztott adathalmaz közepén. Azért, hogy az illesztés a lehető legjobb legyen, a pontfelhőt úgy kell forgatni, hogy a közepén az érintő egyenes vízszintes legyen. A fokszám növelésével csak romlik a görbületfüggvény simasága, így a másodfokú polinom használata a legjobb a feladatra. Ugyanolyan mintavételi sugár esetén a háromszögből és függvényillesztéssel becsült görbületeloszlás nem tér el egymástól a tapasztalat szerint.

\section{Eredmények tárgyalása}

A kiértékelés során több simítást és görbületszámítást is végeztem, az ideális kombináció eredménye a 7. ábrán látható. Az ábrán fel vannak tüntetve a simítási és görbületszámítási adatok, ezek a mozgó ablak szélessége $\left(n_{S}\right)$, a simítási müvelet elvégzésének száma $\left(n_{\text {sim }}\right)$, illetve a görbületszámításhoz felhasznált mintavételi sugár ( $n)$. Az ábrán látható a legkisebb négyzetek módszerével illesztett görbületfüggvény is.

A mért adatokat összevetettem egy korábban kidolgozott numerikus eljárásból [5] nyert eredményekkel. A görbületlefutás (7. ábra) és az alak is jó egyezést mutat (8. ábra). A számításokhoz használt modell a 9. ábrán, az adatok az 1. táblázatban találhatóak.

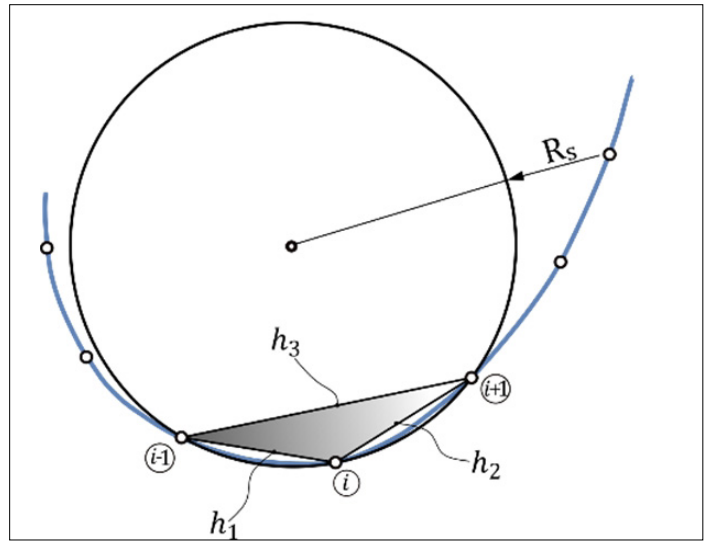

6. ábra. Görbület becslése háromszög köré írt körrel

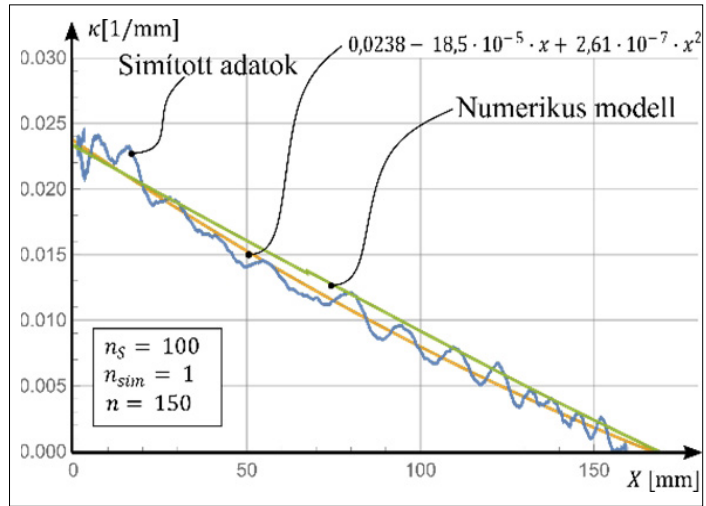

7. ábra. A lemez mért (kék), mérésre illesztett (sárga) és számított (zöld) görbületeloszlása

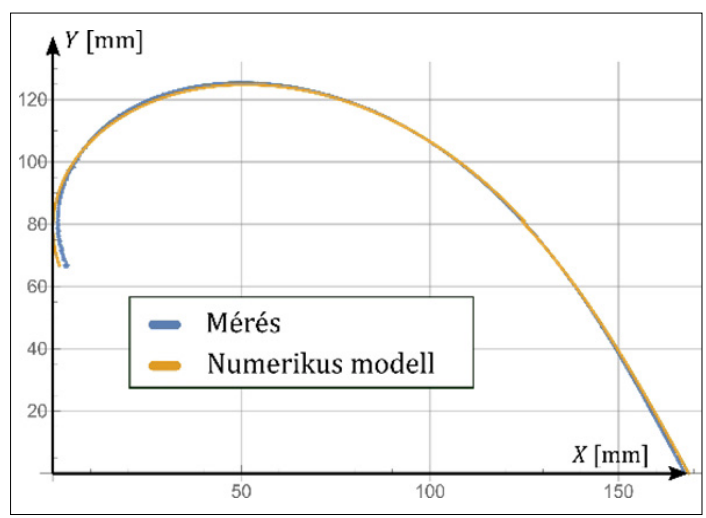

8. ábra. A lemez mért és számított alakja

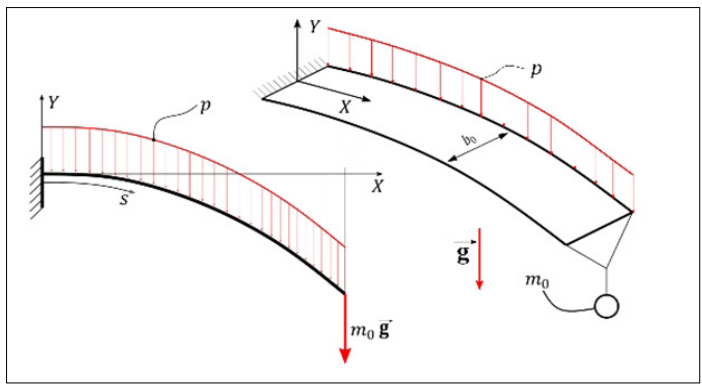

9. ábra. A lemez mechanikai modellje

1. táblázat. Számítási paraméterek

\begin{tabular}{|l|c|c|}
\hline \multicolumn{1}{|c|}{ Paraméter } & Érték & M.egység \\
\hline Rug. modulusz & 200 & $\mathrm{GPa}$ \\
\hline Poisson-tényező & 0.33 & - \\
\hline Lemez hossza & 270 & $\mathrm{~mm}$ \\
\hline$m_{0}$ & 42 & $\mathrm{~g}$ \\
\hline$p$ & $3,27 \cdot 10^{4}$ & $\mathrm{~N} / \mathrm{mm}$ \\
\hline$b_{0}$ & 21 & $\mathrm{~mm}$ \\
\hline
\end{tabular}




\section{Következtetések}

A mérés csupán kísérleti jelleggel készült, nem megfelelően kontrollált körülmények között, ennek ellenére az eredmények meglepően pontosak lettek. A görbületre való következtetés egy pontatlan adathalmazból nehézkes, hiszen ez egy komplex, deriváltakat tartalmazó kifejezés, ennek ellenére ígéretes eredmények adódtak rá. A mérési módszer jelen állapotában nem alkalmas a görbület pontos mérésére, ellenben nem zárja ki a további kísérletezés lehetőségét. Ezzel szemben a módszer az alak mérésére már jelen állapotában is megfelelőnek bizonyult.

\section{Köszönetnyilvánítás}

A cikkben bemutatott kutatás az NKFIH K 134303 sz. pályázatának támogatásával valósult meg.

\section{Szakirodalmi hivatkozások}

[1] Vladimir K.: Curvature in Digital 2D Images. International Journal of Pattern Recognition and Artificial Intelligence, 15/7. (2001) 1183-1200. https://doi.org/10.1142/S0218001401001283

[2] Coeurjolly D., Miguet S., Tougne L.: Discrete Curvature Based on Osculating Circle Estimation. In: Visual Form 2001. $4^{\text {th }}$ International Workshop on Visual Form, IWVF4 Capri, Italy, May 28-30, 2001. Proceedings, 303-312. https://doi.org/10.1007/3-540-45129-3_27

[3] Dalle D.: Comparison of Numerical Techniques for Euclidean Curvature. Rose-Hulman Undergraduate Mathematics Journal, 7/1. Art.12.

[4] Belyaev A. G.: A Note on Invariant Three-Point Curvature Approximations, 数理解析研究所講究録, 1111. (1999) 157-164. (letöltve: 2021.02.15) https://repository.kulib.kyoto-u.ac.jp/dspace/bitstream/2433/63333/1/1111-16.pdf

[5] Máté P., Szekrényes A.: Vékonylemez hengerítési folyamatának numerikus modellezése. Müszaki Tudományos Közlemények, 13. (2020) 133-136. https://doi.org/10.33895/mtk-2020.13.24 